\title{
THE EFFECT OF NON-PERFORMA LOAN AND OPERATIONAL COST OF OPERATIONAL INCOME ON EARNING PER SHARE THROUGH RETURN ON IN PT. BANK SAHABAT SAMPOERNA
}

\section{Dwi Ari Setyowati ${ }^{1}$, Suharto ${ }^{2}$, Harry Indratjahyo ${ }^{3}$}

${ }^{1}$ Student Master of Management Universitas Krisnadwipayana

Campus Unkris Jatiwaringin

PO BOX 7774/Jat CM Jakarta 13077, Indonesia

${ }^{2}$ Associate Professor, Universitas Krisnadwipayana

Campus Unkris Jatiwaringin

PO BOX 7774/Jat CM Jakarta 13077, Indonesia

${ }^{3}$ Lecturer, Universitas Krisnadwipayana

Campus Unkris Jatiwaringin

PO BOX 7774/Jat CM Jakarta 13077, Indonesia

A R T I C L E I N F O
Article history: Article
Received
Revised
Accepted: September, 2020
DOI: $10.47742 /$ ijbssr.v1n2p2

\begin{abstract}
A B S T R A C T
This study aims to: 1) To test and analyze the influence of Non-Performance Loans (NPLs) and Operating Costs Operating Income (BOPO) on Return On Equity (ROE) at PT Bank Sahabat Sampoerna, 2) To test and analyze the influence of Non-Performance Loans (NPL) and Operational Costs Operating Income (BOPO) on the Earning Per Share (EPS) of PT Bank Sahabat Sampoerna, 3) To test and analyze the effect of Return On Equity (ROE) on the Earning Per Share (EPS) of PT Bank Sahabat Sampoerna, 4) To test and analyze Non-Performance Loans (NPL) ), on the Earning Per Share (EPS) through PT Bank Sahabat Sampoerna's Return On Equity (ROE) variable and 5) To test and analyze the Operating Cost of Operating Income (BOPO) on the Earning Per Share (EPS) through PT Bank Sahabat Sampoerna's Return On Equity (ROE).

This study uses secondary data, namely data obtained from the annual report of Bank Sahabat Sampoerna from 2015 - 2018. PT Bank Sahabat Sampoerna with a research sample of 48. The sampling technique uses random sampling techniques. The data analysis method uses descriptive analysis and path analysis.

The results showed that: 1) there was the influence of Non-Performance Loans (NPL) and Operational Income Operating Costs (BOPO) on Return On Equity (ROE) at PT Bank Sahabat Sampoerna, 2) there wasn't an influence of Non-Performance Loans (NPL) and Operating Costs Operational (BOPO) on PT Bank Sahabat Sampoerna's Earning Per Share (EPS), 3) Return on Equity (ROE) not influence on PT Bank Sahabat Sampoerna's Earning Per Share, 4) No Non-Performance Loan (NPL) effect, on the Earning Per Share through the Return On Equity variable (ROE) of PT Bank Sahabat Sampoerna and 5) there is no effect of Operational Income Operating Costs (BOPO) on the Earning Per Share (EPS) through the Return on Equity (ROE) of PT Bank Sahabat Sampoerna.
\end{abstract}

Keywords : Non-Performance Loans (NPL), Operational Costs Operating Income (BOPO), Return On Equity (ROE) and Earning Per Share (EPS)

\section{Introduction}

The introduction is the first impression of the article. The opening paragraphs of the article will Banks are one of the financial institutions that play an important role in the economy in Indonesia. According to Law No. 10 of 1998, a bank is a financial intermediary institution, where a bank is an institution to collect public funds in the form of credit and/or other forms to improve the standard of living of many people. The role of a bank is an institution that acts as a financial intermediary between parties that have excess funds.

Banking in Indonesia functions as a collector and channel of public funds and aims to support the implementation of national development to increase equitable development and its results, economic growth and national stability, increase the standard of living of the people at large. Banking has a strategic position, namely as a support for the smooth payment system, monetary policy, and crisis in the payment system, monetary policy, and financial system, so it is necessary to have a healthy, transparent, and accountable banking system.

Research on the banking industry is always interesting to observe because banking is a supporting financial institution that is always directly related to economic activity. This is inseparable from the role of the bank itself as an intermediary between parties with excess funds and parties who are underfunded, namely the place where the circulation and financial transactions take place and is also a means of supporting the development of the national economy. In addition to the above, historical records have proven that banking stocks can provide attractive rates of return (capital gain) for investors. 


\section{Vol: 1, Issue: 2}

October $/ 2020$

https://ijbssrnet.com/index.php/ijbssr

DOI: $10.47742 /$ ijbssr.v1n2p2

One of the banks that is starting to develop in Indonesia is Bank Sahabat Sampoerna. Bank Sampoerna was born from the acquisition of a national private bank in May 2011 and is supported by two well-known business groups in Indonesia, namely the Sampoerna Strategic Group through PT. Sampoerna Investama and the alpha Group through Cakrawala Mulia Prima. Focus on MSMEs to upgrade to a larger scale. Currently, it has 20 bank office networks throughout Indonesia and is supported by GPN ATM services and mobile banking. Partnering with the Sahabat Mitra Sejati (Sahabat UKM) Savings and Loan Cooperative which is well known in Sumatra, Java, Kalimantan, Sulawesi, and Papua.

In running the banking operational business, BSS cannot be separated from the risks it faces. These risks include bank operational risk and bank credit risk. Bank operational risk arises from bank management and if it is wrong to maintain it, it will have an impact on the downfall of the company. Meanwhile, bank credit risk is caused by bad or uncollectible bank credit.

NPL or Non-Performing Loan is one of the indicators of the health quality of bank assets. This indicator is a principal financial ratio that can provide information on the condition of capital, profitability, credit risk, market risk, and liquidation. The
NPL used is net NPL, namely the NPL which is already unbeatable. Asset quality assessment is a guarantee of the condition of bank assets and the adequacy of credit risk management. This means that the NPL is an indication of a problem in the bank, which if it does not immediately get a solution, it will have a bad impact on the bank. NPL, which is also known as non-performing loans, can have an impact on reducing bank capital. If this is allowed, it will have an impact on lending in the next period.

According to Bank Indonesia Regulation Number, 6/10 / PBI / 2004 dated April 12, 2004, concerning the Rating System for Commercial Banks, it is stated that the ratio of nonperforming loans (NPL) is 5\%. Bank Indonesia provides a ratio against this bad credit which is known as the Non-Performing Loan (NPL). NPL is also known as the non-performing loan ratio. Total non-performing loans are loans categorized as substandard, doubtful, and non-performing loans. Bank has a certain length of time to define this. Under-credit credits are those that may still be collectible. Doubtful credit is credit that is very difficult to collect while bad credit is credit that cannot be collected. The development of NPLs in Bank BSS from 2015 to 2018 can be seen in the following graph:

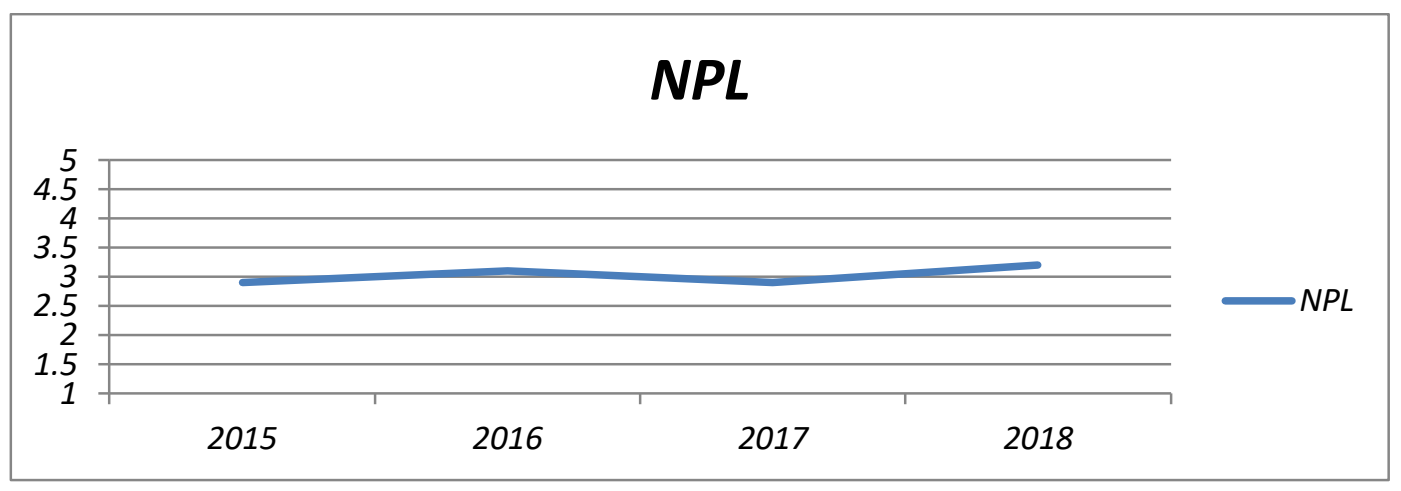

Figure 1. BSS NPL Growth

Based on the chart above, BSS NPL experienced worsening in 2018 compared to 2015-2017. Another factor that needs to be considered in predicting Earning Per Share (EPS) is the ratio of Operating Costs to Operating Profit (BOPO). Bank operational costs are bank fees which consist of all costs in carrying out banking while operating income is all income earned by the bank in a certain period.

BOPO is the ratio of operating costs to operating income, which is a proxy for operational efficiency as commonly used by Bank Indonesia (Kuncoro, 2002, 570). The more efficient a bank's operational performance is, the greater the benefits it will get. For bank management, this shows the importance of paying attention to costs to produce an OEOI ratio following the provisions set by the monetary authority (Kuncoro, 2002, 573)

BOPO is a bank's effort to minimize operational risk, which represents uncertainty regarding the bank's business activities. Operational risk may arise from operational losses if there is a decrease in profits which is influenced by the bank's operational cost structure, and the possibility of failure of the services and products offered.
Financial ratios can be used by investors as a tool to analyze the company's ability to generate profits based on the shares owned. This shows that financial ratios are useful in assessing the company's financial condition. The value of the company's shares is reflected in the company's performance. If the company's financial performance shows a good prospect, the shares will be in demand by investors and the price will increase. This shows that there is a positive relationship between the company's financial performance and its Earning Per Share (EPS). Ratios that can be used by investors include Return on Assets (ROA), Return on Equity (ROE), Net Profit Margin (NPM), and Earning Per Share (EPS) (Raharjo and Dul, 2013: 1).

Return on Equity (ROE) is a ratio used to measure the net profit obtained from managing the capital invested by the owner of the company. ROE is measured by the ratio between net income and total capital. The higher ROE figure indicates shareholders that the return on investment is higher and Earning Per Share (EPS) tends to be high (Lestari and Toto, 2007: 196).

ROE is a ratio that describes the extent to which the company's ability to generate profits can be obtained bv 


\section{Vol: 1, Issue: 2} October $/ 2020$

https://ijbssrnet.com/index.php/ijbssr DOI: 10.47742/ijbssr.v1n2p2

shareholders. Earnings Per Share (EPS) is a ratio that many potential investors pay attention to because EPS information is considered the most basic information and can describe the company's future earnings prospects (Tandelilin, 2010: 378).

In general, company management, common shareholders, and prospective shareholders are interested in EPS, because this describes the amount of rupiah obtained for each common share (Syamsuddin, 2009: 66). To find out whether the above variables affect Earning Per Share (EPS) through ROE BSS, the researcher puts forward the title Effect of NPL and BOPO on EPS through ROE at PT. Bank Sahabat Sampoerna.

\section{Literature Review}

\section{Non-Performa Loan (NPL)}

Non-Performance Loans (NPL) or non-performing loans are one of the key indicators for assessing the performance of bank functions. One of the functions of a bank is as an intermediary institution or a liaison between parties who have excess funds and those who need funds.

Bank Indonesia (BI) through a Bank Indonesia Regulation (PBI) stipulates that the non-performing loan (NPL) ratio is $5 \%$. Based on this, it can be concluded that several things affect or can cause a bank's NPL to fluctuate, including the following:

\section{a. Willingness or good faith of the debtor:}

From a financial perspective, the debtor's ability to pay off the principal and interest on the loan will be meaningless without the willingness and good faith of the debtor himself.

b. Government and Bank Indonesia policies:

Government policies can affect the level of NPL of a bank, for example, government policies regarding fuel price increases will cause companies that use a lot of fuel in their production activities to require additional funds taken from budgeted profits for debt repayment payments to meet high production costs, so that the company it will experience difficulties in paying its debts to the bank. Likewise, with PBI, Bank Indonesia regulations have a direct or indirect effect on a bank's NPL. For example, BI raises the BI Rate which will cause credit interest rates to rise, by itself the debtor's ability to pay off principal and loan interest will decrease.

c. Economic conditions:

Economic conditions have a great influence on the ability of debtors to pay off their debts. Macroeconomic indicators that have an impact on NPL include the following:

d. Inflation:

Inflation is an increase in prices as a whole and continuously. High inflation can reduce the ability of debtors to pay off their debts.

\section{e. Rupiah exchange rate:}

The rupiah exchange rate also affects the NPL of a bank because the debtor banking activity is not only national but also international.

Non-Performing Loan (NPL) is the rate of return on credit given by depositors to banks, in other words, NPL is the level of credit at the bank. The amount of NPL allowed by Bank Indonesia is currently a maximum of 5\%. NPL (Non-Performing
Loan) is a ratio that shows the ability of bank management to manage non-performing loans provided by the bank. NPL relates to bank credit risk. The bank risk profile is a description of the main risks that exist in bank activities. Banks in running a business contain various kinds of risks. The risk profile is a summary that provides an overview of risk management which needs attention.

Bank Indonesia categorizes risk into credit risk, market risk, liquidity risk, operational risk, compliance risk, strategic risk, reputation risk, and legal risk. For the eight risks, it can be determined what risks need to be prioritized by management to be managed properly, because they are considered to be potentially detrimental to the bank. In assessing the risk profile, banks are also required to pay attention to the scope of risk management implementation as stipulated in Bank Indonesia regulations concerning the application of risk management for commercial banks.

Inherent risk assessment is an assessment of the risks inherent in the Bank's business activities, both quantifiable and non-quantifiable, which have the potential to affect the Bank's financial position. The inherent risk characteristics of the Bank are determined by internal and external factors, including business strategy, business characteristics, the complexity of bank products and activities, the industry in which the bank conducts business activities, and macroeconomic conditions. Assessment of inherent risk is carried out by taking into account quantitative and qualitative parameters or indicators.

Non-Performing Loans (NPL), the ratio of loans is proxied by Non-Performing Loans (NPL), which is the ratio between total non-performing loans to total loans extended. (Christiano, Tommy, and Saerang: 2014). Non-Performing Loans (NPL) is the ratio between non-performing loans to total loans. Non-Performing Loan (NPL) is one of the key indicators for assessing the performance of bank functions. One of the functions of a bank is as an intermediary institution or a liaison between parties who have excess funds and those who need funds. This ratio shows the ability of bank management to manage non-performing loans. The higher this ratio, the worse the quality of bank credit, meaning that the number of nonperforming loans is getting bigger (Eng, 2013).

Research on credit risk was carried out by Wisnu (2004) which states that a high Non-Performing Loan (NPL) condition will increase the cost of both the cost of reserves for productive assets and other costs so that it has the potential to cause losses to the bank, or in other words, a non-performing loan. (NPL) reduces bank profitability. This shows that the Non-Performing Loan (NPL) harms profitability.

\section{Operating Costs On Operating Income (BOPO)}

BOPO includes the ratio of profitability (earnings). The success of a bank is based on a quantitative assessment of bank profitability which can be measured using the ratio of operating costs to operating income (Kuncoro and Suhardjono, 2002). According to Dendawijaya (2005), the ratio of operational costs is used to measure the level of efficiency and the ability of a bank to carry out its operations. Meanwhile, according to (Almilia and 


\section{Vol: 1, Issue: 2} October $/ 2020$

https://ijbssrnet.com/index.php/ijbssr DOI: $10.47742 /$ ijbssr.v1n2p2

Herdiningtyas, 2005), the ratio of Operating Costs to Operating Income (BOPO) is often called the efficiency ratio, which is used to measure the ability of the bank management to control operating costs against operating income. The smaller the ratio, the more efficient the operational costs incurred by the bank concerned.

Operating expenses are calculated based on the sum of total interest expense and total other operating expenses, and operating income is the sum of total interest income and total other operating income. The complete components of income and operating expenses according to Kasmir (2013: 284) are as follows:

a. Interest income, this post includes all bank income in the form of interest in rupiah and foreign currency (foreign currency) in its operational activities. This account also includes income in the form of commissions and fees received in the context of providing credit.

b. Interest expenses, this post includes all expenses paid by banks in the form of interest expenses in rupiah and foreign currencies to residents and non-residents alike. This post also includes commissions and fees paid by the bank in the form of loan commissions/provisions.

c. Other operating income, this post contains other operating income from residents and non-residents, consisting of provision income, foreign exchange transaction income, income from an increase in securities value.

d. Expenses (income) for write-offs of earning assets.

e. Expenses for estimated losses on commitments and contingencies, this account contains depreciation amortization/write-offs on administrative account transactions.

f. Other operating expenses, this post contains all expenses incurred by the bank to support its operational activities.

\section{Return On Equity (ROE)}

The definition of Return On Equity according to Sartono (2010: 124) is to measure the company's ability to obtain available profits for the company's shareholders. This ratio is influenced by the size and size of the company's debt, if the proportion of debt is greater, this ratio will be even greater, while the definition of Return On Equity according to Brigham and Houston (2010: 149), namely the ratio of net to ordinary equity measures the rate of return on shareholder investment the usual.

The definition of Return On Equity according to Irham (2012: 98) is a ratio used to examine the extent to which a company affects its resources to be able to provide a return on equity. According to Kasmir (2013: 204) is to measure net profit after tax with its capital. This Return On Equity ratio shows the efficient use of its capital. The higher the ratio, the better. This means that the company's position will be stronger, and vice versa.

Irawan (2011) in his research found that the results of Return On Equity (ROE) affect earnings growth. This is due to the very precise nature and pattern of investment made by the company so that all assets can be used efficiently so that profits are maximized. Besides, the income generated by capital from debt can be used to cover the cost of capital. Return on Equity is generally calculated for common shareholders. In this case, the preferred dividend is not included in the calculation because that type of dividend is not available to ordinary shareholders. Usually, the preferred dividend is excluded from the calculation of net income.

\section{Earnings Per Share (EPS)}

Earnings Per Share (EPS) according to Husnan and Pudjiastuti (2004: 151) is the present value (Present Value) of income that will be received by investors and received by investors in the future. Meanwhile, according to Jogiyanto (2008: 143) Earning Per Share (EPS) is the price that occurs on the stock market at a certain time and the Earning Per Share (EPS) is determined by market players. The level of Earning Per Share (EPS) is determined by the demand and supply of these shares in the capital market.

Investors have various objectives in investing in the capital market, one of which is to gain profits on their share investment in the form of an increase in Earning Per Share (EPS) or dividends. Following the basic objective of a company, namely maximizing profits, every policy related to maximizing Earning Per Share (EPS) is always closely related to the company's ability to increase prosperity both to increase company value and to maximize the prosperity of its shareholders.

According to Gitosudarmo and Basri (2002: 7) maximizing shareholder wealth can be measured from earnings per share (EPS) so that in this case EPS will affect investor confidence in the company. Besides that, according to Brigham and Houston (2006: 33-34), there is a high correlation between Earning per Share, cash flow, and Earning Per Share (EPS). Earnings per Share is one indicator of the success that the company has achieved in creating profits for its shareholders. According to Wiguna and Mendari (2008) in EPS stock trading is very influential on Earning Per Share (EPS). The higher the EPS, the more expensive a stock will be, and vice versa because EPS is a form of financial ratio to assess the company's performance.

EPS is the portion of the company's profit that is allocated to each share outstanding. Earnings per share or Earning per Share is the most widely used indicator to assess the profitability of a company. Earnings per share is a very useful measure of profitability and when compared to Earnings per Share in similar companies, Earnings per Share will provide a very clear picture of the strength of profitability between the company concerned and its comparison company. Please note that the comparison company must be a company operating in the same type of industry. Earnings per Share or EPS, if calculated for several years, will show whether the company's profitability is getting better or worse. Investors will usually invest their funds in companies whose earnings per share continues to increase.

EPS (Earning per Share) growth is an important measure of a company's performance because it shows how much money a company makes for its shareholders. Not only because of 
http://iarpnet.org/

changes in profits but also after all the impact of issuing new shares.

If there is a change in the capital structure (for example a change in the number of shares) during the reporting period, the shares outstanding must be calculated based on the weighted average share outstanding during the year.

Research Method

Time and Location of Research
Vol: 1, Issue: 2

October $/ 2020$

https://ijbssrnet.com/index.php/ijbssr DOI: 10.47742/ijbssr.v1n2p2

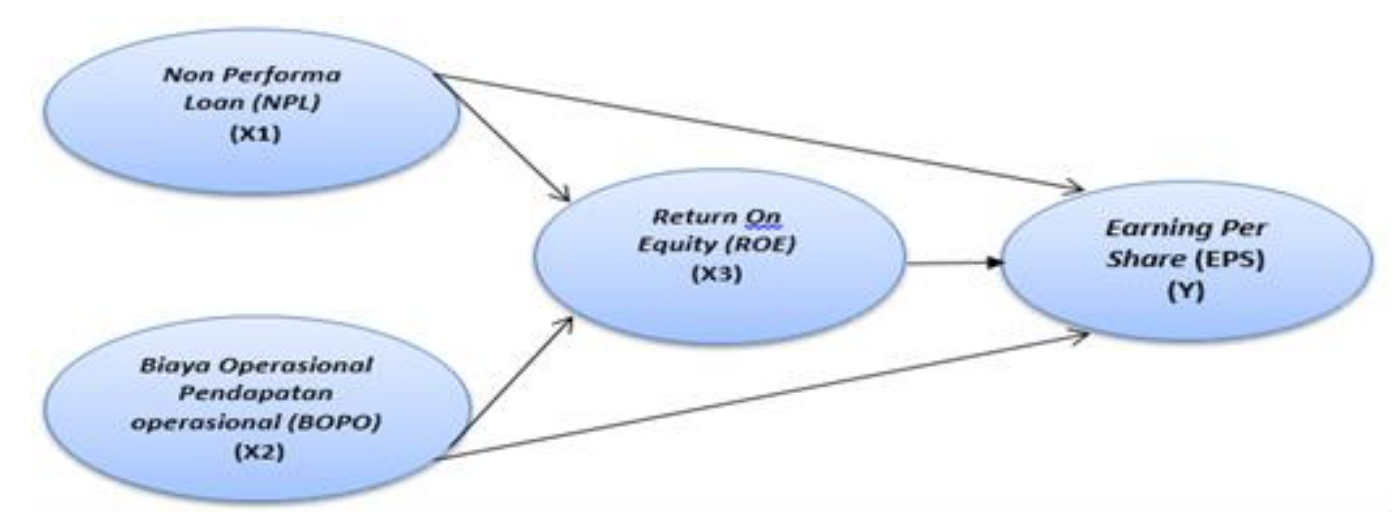

Figure 2. Research Design

\section{Data Source}

Data sources Sunyoto (2013: 21) explains that in a study there are two sources of data that can be used, namely:

1. Primary data is the original data collected by the researcher to answer the problem he is researching specifically. This primary data is usually not available, so researchers must collect and process it themselves based on needs.

2. Secondary Data is data that comes from existing records in the company and from other sources, namely by conducting literature studies and studying books that are related to the object of research.
This research was conducted at Bank Sahabat Sampoerna Jakarta, at the Sampoerna Strategic Square Building, with an estimated research time of three years from 2015 to 2018 .

\section{Research Design}

This study uses an explanatory analysis approach. This means that every variable that is presented in the hypothesis will be observed by testing the causal relationship between the independent variable and the dependent variable. This phenomenon can be designed through the following mathematical functions:

This study uses secondary data, namely data that the authors get from other published or available sources in the form of Bank Sahabat Sampoerna's annual reports from 2015 - 2018.

\section{Data Analysis Technique}

The data analysis technique uses path analysis.

\section{Research Results and Discussion}

1. Analysis of the Influence of Non-Performance Loans (NPL) and Operating Costs Operating Income (BOPO) on Return On Equity (ROE)

According to Ghozali (2006: 211), the path coefficient uses standardized regression coefficients. The results of the regression analysis of the effect of Non-Performance Loans (NPL) and Operating Costs (BOPO) on Return on Equity (ROE) can be seen in the table below:

Table 1. The Results of Simultaneous Non-Performing Loan (NPL) and Operating Costs Operating Income (BOPO) Against Return On Equity (ROE) Model Summary ${ }^{\mathrm{b}}$

\begin{tabular}{llrrr}
\hline Model & R & R Square & $\begin{array}{c}\text { Adjusted R } \\
\text { Square }\end{array}$ & $\begin{array}{c}\text { Std. Error of the } \\
\text { Estimate }\end{array}$ \\
\hline 1 & $.445^{\text {a }}$ & .198 & .163 & 19.52470
\end{tabular}

a. Predictors: (Constant), NPL, BOPO

b. Dependent Variable: ROE

Source: Primary data processed, 2020

Table 1, shows the value of R2 (R Square) of 0.192 . The value of $\mathrm{R} 2$ is used in calculating the value of the e1 coefficient. The e1 coefficient is a variant of Return On Equity
(ROE) which is not explained by Non-Performing Loans (NPL) and Operating Expenses for Operating Income (BOPO). The amount:

$$
\text { Coefficient } \mathrm{e}_{1}=\sqrt{\left(1-R^{2}\right)}=\sqrt{(1-0,192)}=\sqrt{0,808}=0,898
$$


Table 2. Regression Analysis Return On Equity (ROE)

Coefficients $^{\mathbf{a}}$

\begin{tabular}{|c|c|c|c|c|c|c|}
\hline \multirow[b]{2}{*}{ Model } & & \multicolumn{2}{|c|}{$\begin{array}{l}\text { Unstandardized } \\
\text { Coefficients }\end{array}$} & \multirow[t]{2}{*}{$\begin{array}{l}\text { Standardized } \\
\text { Coefficients }\end{array}$} & \multirow[b]{2}{*}{$\mathrm{t}$} & \multirow[b]{2}{*}{ Sig. } \\
\hline & & $\mathrm{B}$ & Std. Error & & & \\
\hline 1 & (Constant) & 131.874 & 104.433 & & 1.263 & .013 \\
\hline & BOPO & .197 & .090 & .387 & 2.184 & .034 \\
\hline & NPL & 1.015 & .304 & .592 & 3.337 & .002 \\
\hline
\end{tabular}

a. Dependent Variable: ROE

Source: Primary data processed, 2020

Based on Table 2, it can be seen that the regression equation is as follows: $\mathrm{X}_{3}=$

$$
\mathrm{b}_{1} \mathrm{X}_{1}+\mathrm{b}_{2} \mathrm{X}_{2}+\mathrm{e}_{1}
$$$$
\mathrm{X}_{3}=0,090 \mathrm{X}_{1}+0,304 \mathrm{X}_{2}+0,898 \mathrm{e}_{1}
$$

The equation shows that:

a. Each time there is an increase in 1 Non-Performance Loan (NPL), an increase in Return On Equity (ROE) will be followed by 0.090 .
Vol: 1, Issue: 2

October $/ 2020$

https://ijbssrnet.com/index.php/ijbssr DOI: 10.47742/ijbssr.v1n2p2 
Table 4. Regression Analysis Earning Per Share (EPS) Coefficients $^{\mathrm{a}}$

\begin{tabular}{|c|c|c|c|c|c|c|}
\hline \multirow[b]{2}{*}{ Mod } & & \multicolumn{2}{|c|}{$\begin{array}{l}\text { Unstandardized } \\
\text { Coefficients }\end{array}$} & $\begin{array}{l}\text { Standardized } \\
\text { Coefficients }\end{array}$ & \multirow[b]{2}{*}{$\mathrm{t}$} & \multirow[b]{2}{*}{ Sig. } \\
\hline & & B & Std. Error & Beta & & \\
\hline \multirow[t]{4}{*}{1} & (Constant) & 7175.444 & 2012.052 & & 3.566 & .001 \\
\hline & NPL & 8.873 & 6.430 & .270 & 1.380 & .005 \\
\hline & BOPO & 5.986 & 1.801 & .612 & 3.324 & .002 \\
\hline & ROE & 4.046 & 2.822 & .211 & 1.434 & .009 \\
\hline
\end{tabular}

a. Dependent Variable: EPS

Source: Primary data processed, 2020

Based on Table 4, it can be seen that the regression equation is as follows:

$\mathrm{Y}=\mathrm{b}_{1} \mathrm{X}_{1}+\mathrm{b}_{2} \mathrm{X}_{2}+\mathrm{b}_{3} \mathrm{X}_{3}+\mathrm{e}_{2}$

$\mathrm{Y}=0,270 \mathrm{X}_{1}+0,612 \mathrm{X}_{2}+0,211 \mathrm{X}_{3}+0,874 \mathrm{e}_{2}$

b) Every time there is an increase of 1 unit of Operational Income to Operational Cost (BOPO), it will be followed by an increase in Earning Per Share (EPS) of 0.612.

c) Every time there is an increase of 1 unit of Return On Equity (ROE), it will be followed by an increase in Earning Per Share (EPS) of 0.211.
Vol: 1, Issue: 2

October $/ 2020$

https://ijbssrnet.com/index.php/ijbssr

DOI: 10.47742/ijbssr.v1n2p2

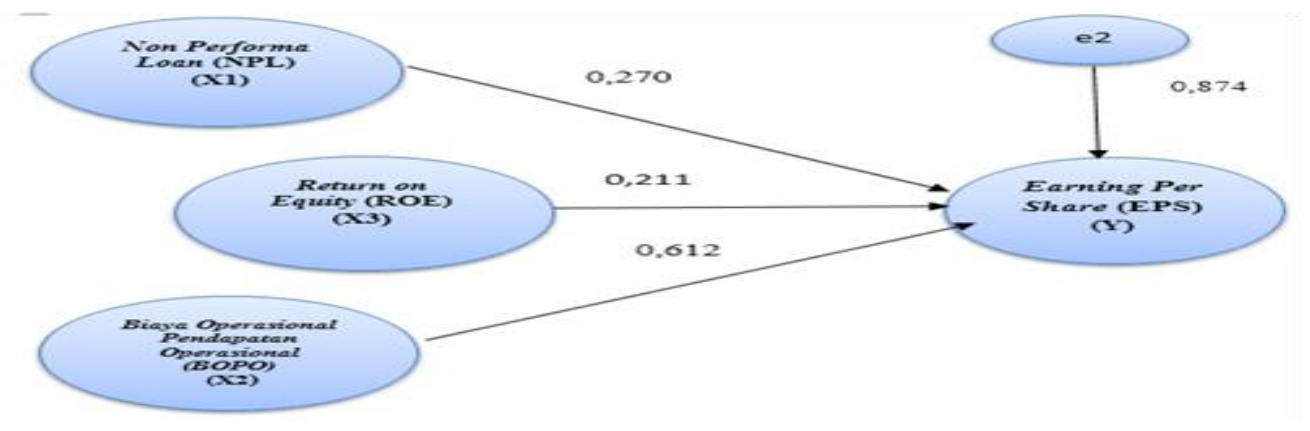

Source: Primary data processed, 2020

Substructure Equation (1) dan (2)

Figure 4. Substructure Equation 2

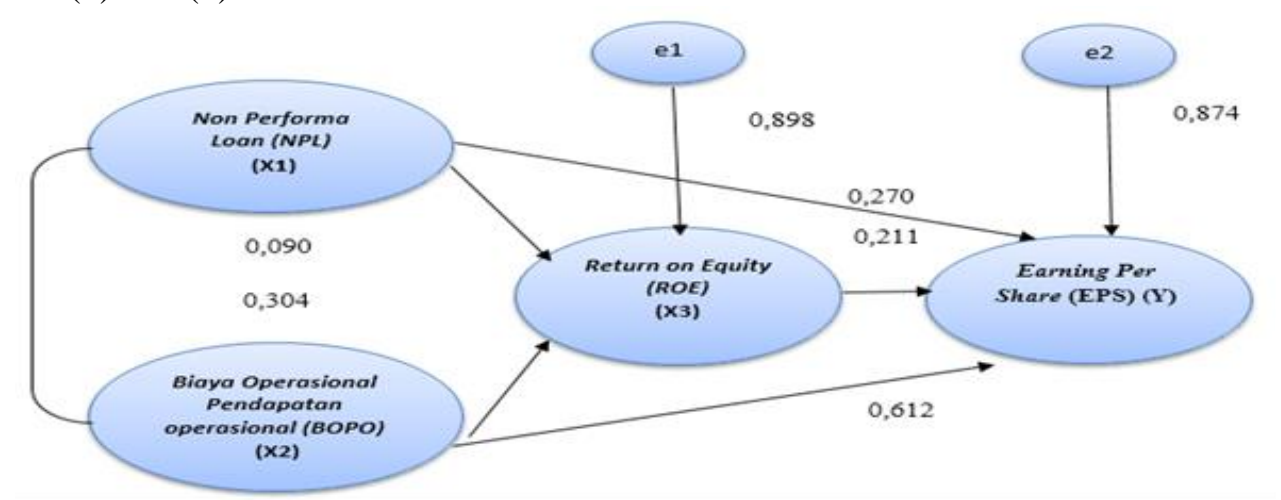

Source: Primary data processed, 2020

Hypothesis Test

Figure 5. Overall Path Analysis

1. It is suspected that there is an effect of non-performing loans (NPL) and operating costs, operating income (BOPO) on the Return on Equity (ROE) at PT Bank Sahabat Sampoerna.

To find out this, it is necessary to use the t-test. The following is a test of each variable: 
Vol: 1, Issue: 2

October/2020

https://ijbssrnet.com/index.php/ijbssr

DOI: 10.47742/ijbssr.v1n2p2

(C)The Institute of Academic Research and Publication

http://iarpnet.org/

Table 5. T-Test Results Effect of Non-Performing Loans (NPL) and Operating Costs Operating Income (BOPO) on Return On Equity (ROE)

\begin{tabular}{|c|c|c|c|c|c|}
\hline \multirow[b]{2}{*}{ Model } & \multicolumn{2}{|c|}{$\begin{array}{c}\text { Unstandardized } \\
\text { Coefficients }\end{array}$} & \multirow{2}{*}{$\begin{array}{c}\begin{array}{c}\text { Standardized } \\
\text { Coefficients }\end{array} \\
\text { Beta } \\
\end{array}$} & \multirow[b]{2}{*}{$\mathbf{t}$} & \multirow[b]{2}{*}{ Sig. } \\
\hline & $\mathrm{B}$ & Std. Error & & & \\
\hline 1 (Constant) & 131.874 & 104.433 & & 1.263 & .013 \\
\hline BOPO & .197 & .090 & .387 & 2.184 & .034 \\
\hline NPL & 1.015 & .304 & .592 & 3.337 & .002 \\
\hline
\end{tabular}

a. Dependent Variable: ROE

Source: Primary data processed, 2020

From Table 5, it is found that the t-count value of the Operating Income (BOPO) affects Return On Equity (ROE). Non-Performance Loan (NPL) variable is 3.337, while the t-table Thus the first hypothesis is tested and proven. value is 1.687 . T-count> t-table (3.337> 1.687), thus $\mathrm{H} 0$ is rejected and $\mathrm{H} 1$ is accepted at the real level. This concludes that Non-Performance Loans (NPLs) affect Return On Equity (ROE).

The $\mathrm{t}$-count value of the Operational Cost of Operational

2. It is suspected that there is an effect of Non-Performing Loans (NPL) and Operating Costs Operating Income (BOPO) on Earning Per Share (EPS) at PT Bank Sahabat Sampoerna.

Income (BOPO) is 2.184, while the t-table is 1.687. T-count> t- To test the effect of Non-Performing Loans (NPL) and Operating table (2.184> 1.687), thus H0 is rejected and H1 is accepted at Costs Operating Income (BOPO) on Earning Per Share (EPS), the real level. This concludes that the Operational Cost of the t-test is used. The following are the results of the t-test:

Table 6. T-test Results Effect of Non-Performing Loans (NPL) and Operating Costs Operating Income (BOPO) on Earning Per Share (EPS)

Coefficients $^{\mathbf{a}}$

\begin{tabular}{|c|c|c|c|c|c|c|}
\hline \multirow{2}{*}{\multicolumn{2}{|c|}{ Model }} & \multicolumn{2}{|c|}{$\begin{array}{l}\text { Unstandardized } \\
\text { Coefficients }\end{array}$} & $\begin{array}{c}\text { Standardized } \\
\text { Coefficients }\end{array}$ & \multirow[b]{2}{*}{$\mathbf{t}$} & \multirow[b]{2}{*}{ Sig. } \\
\hline & & $\mathrm{B}$ & Std. Error & Beta & & \\
\hline \multirow[t]{4}{*}{1} & (Constant) & 7175.444 & 2012.052 & & 3.566 & .001 \\
\hline & NPL & 8.873 & 6.430 & .270 & 1.380 & .005 \\
\hline & BOPO & 5.986 & 1.801 & .612 & 3.324 & .002 \\
\hline & ROE & 4.046 & 2.822 & .211 & 1.434 & .009 \\
\hline
\end{tabular}

a. Dependent Variable: EPS

Source: Primary data processed, 2020

From Table 6, it is found that the t-count value of the Non- accepted at that real level. This concludes that the Operating Performance Loan (NPL) variable is 1.819 , while the t-table Costs Operational Income (BOPO) affects Earning Per Share value is 1.687 . Thus tcount> t-table (1.380> 1.687), thus H0 is (EPS). Thus the second hypothesis is not tested and proven. accepted and $\mathrm{H} 1$ is rejected at that real level. This concludes that 3. It is suspected that there is an effect of Return On Equity the Non-Performance Loan (NPL) does not affect Earning Per Share (EPS).

(ROE) on PT Bank Sahabat Sampoerna's Earning Per Share (EPS).

The t-count value of the Operational Cost of Operating Income To test the effect of Return On Equity (ROE) on Earning Per (BOPO) variable is 3.324 while the t-table value is 1.687 . T- Share (EPS), the t-test is used. The following are the results of count> t-table (3.324> 1.687), thus $\mathrm{H} 0$ is rejected and $\mathrm{H} 1$ is the t-test:

Table 7. Effect of the Effect of Return on Equity (ROE) on Earning Per Share (EPS)

Coefficients $^{\mathrm{a}}$

\begin{tabular}{llrrrrrr} 
& & \multicolumn{2}{c}{ Unstandardized } & \multicolumn{2}{c}{$\begin{array}{c}\text { Standardized } \\
\text { Coefficients }\end{array}$} & & \\
\cline { 3 - 5 } Model & & \multicolumn{1}{c}{ B } & \multicolumn{1}{c}{ Std. Error } & Beta & & \multicolumn{1}{c}{ Sig. } \\
\hline 1 & (Constant) & 7175.444 & 2012.052 & & & 3.566 & .001 \\
& NPL & 8.873 & 6.430 & .270 & 1.380 & .005 \\
& BOPO & 5.986 & 1.801 & .612 & 3.324 & .002 \\
& ROE & 4.046 & 2.822 & .211 & 1.434 & .009
\end{tabular}

a. Dependent Variable: EPS

Source: Primary data processed, 2020 


\section{Vol: 1, Issue: 2}

October/2020

https://ijbssrnet.com/index.php/ijbssr DOI: 10.47742/ijbssr.v1n2p2

The results of the t-test for the variable Return On Equity (ROE) obtained the value of $t$ count $=1.434$, and the t-table of 1.687. This means that $\mathrm{t}$-count $>\mathrm{t}$-table $(1.434>1.687)$, which means that $\mathrm{H} 0$ is rejected and $\mathrm{H} 1$ is accepted. This concludes that Return On Equity (ROE) to Earning Per Share (EPS). Thus the third hypothesis is not tested and proven.

4. It is suspected that there is an effect of Non-Performance Loans (NPL) on Earning Per Share (EPS) through PT Bank Sahabat Sampoerna's Return On Equity (ROE) variable. $\mathrm{X} 1 \rightarrow \mathrm{X} 3 \rightarrow \mathrm{Y}=(\rho \mathrm{x} 3 \mathrm{x} 1) \mathrm{x}(\rho \mathrm{yx} 3)=0.592 \times 0.211=0.125$

The indirect effect value 0.125 is obtained from the path coefficient value $\rho \times 3 \times 1$ multiplied by the path coefficient value pyx3. The value of the direct effect of Non-Performance Loans (NPL) on Earning Per Share (EPS) is 0.270. The multiplication result shows that the value of the indirect effect coefficient is smaller than the value of the direct effect coefficient. This shows that Return On Equity (ROE) cannot mediate, namely NonPerformance Loans (NPL) to Earning Per Share (EPS).

5. It is suspected that there is an effect of operational costs operating income (BOPO) on Earning Per Share (EPS) through the variable Return on Equity (ROE) of PT Bank Sahabat Sampoerna.

$\mathrm{X} 2 \rightarrow \mathrm{X} 3 \rightarrow \mathrm{Y}=(\rho \mathrm{x} 3 \mathrm{x} 2) \times(\rho \mathrm{yx} 3)=0.387 \times 0.211=0.082$

The value of the indirect effect of 0.082 is obtained from the path coefficient value $\rho \times 3 \times 1$ multiplied by the path coefficient value $\rho y x 3$. The value of the direct effect of Non-Performance Loans (NPL) on Earning Per Share (EPS) is 0.612. The multiplication result shows that the value of the indirect effect coefficient is smaller than the value of the direct effect coefficient. This shows that Return On Equity (ROE) cannot mediate, namely the Operational Cost of Operating Income (BOPO) to Earning Per Share (EPS).

\section{Total Effect}

a. Effect of Non-Performance Loans (NPL) on Earning Per Share (EPS) through PT Bank Sahabat Sampoerna's Return On Equity (ROE) variable.

$\mathrm{X} 1 \rightarrow \mathrm{X} 3 \rightarrow \mathrm{Y}=\rho \mathrm{yx} 1+\{(\rho \mathrm{x} 3 \mathrm{x} 1) \mathrm{x}(\rho \mathrm{yx} 3)\}=0.592+$ $0.125=0.717$
The total influence arising from Non-Performance Loans (NPL) on Earning Per Share (EPS) through the Return On Equity (ROE) variable is 0.717 .

b. The Influence of Operational Costs Operating Income (BOPO) on Earning Per Share (EPS) through PT Bank Sahabat Sampoerna's Return On Equity (ROE) variable. $\mathrm{X} 2 \rightarrow \mathrm{X} 3 \rightarrow \mathrm{Y}=\rho \mathrm{yx} 2+\{(\rho \mathrm{x} 3 \mathrm{x} 2) \mathrm{x}(\rho \mathrm{yx} 3)\}=0.387+$ $0.082=0.469$

c. The total effect arising from the Operational Costs Operating Income (BOPO) on Earning Per Share (EPS) through the Return On Equity (ROE) variable is 0.469. Effect of Return On Equity (ROE) on Earning Per Share (EPS) of PT Bank Sahabat Sampoerna.

$\mathrm{X} 1 \rightarrow \mathrm{Y}=\rho \mathrm{yx} 1=0.211$

d. The total effect that arises from Return On Equity (ROE) on Earning Per Share (EPS) is 0.211.

Effect of Non-Performance Loans (NPL) on PT Bank Sahabat Sampoerna's Earning Per Share (EPS) variable. $\mathrm{X} 1 \rightarrow \mathrm{Y}=\rho \mathrm{yx} 1=0.270$

e. The total influence arising from Non-Performing Loans (NPL) on Earning Per Share (EPS) is 0.270.

The Influence of Operational Costs Operating Income (BOPO) on PT Bank Sahabat Sampoerna's Earning Per Share (EPS).

$\mathrm{X} 2 \rightarrow \mathrm{Y}=$ pyx $1=0.612$

f. The total influence arising from Operating Costs Operating Income (BOPO) on Earning Per Share (EPS) is 0.612 .

g. Effect of PT Bank Sahabat Sampoerna Residual Return On Equity (ROE) Coefficient Variables.

The coefficient of e1 $=0.898$

h. Effect of Variable Residual Price Coefficient of PT Bank Sahabat Sampoerna

The coefficient of e $2=0.874$

\section{The Coefficient Of Determination}

The coefficient of determination (R2) in essence measures how far the model's ability to explain the variation in the dependent variable.

Table 8. Coefficient of Determination with Dependent Variables Return On Equity (ROE) Model Summary

\begin{tabular}{lrrrr}
\hline Model & R & R Square & Adjusted R Square & Std. Error of the Estimate \\
\hline 1 & $.445^{\text {a }}$ & .198 & .163 & 19.52470 \\
\hline a. Predictors: (Constant), NPL, BOPO & & \\
b. Dependent Variable: ROE
\end{tabular}

Source: Primary data processed, 2020

Based on multiple linear analyses in Table 12, the determinant Non-Performance Loans (NPL) and Operating Costs Operating coefficient R2 is 0.198 on the dependent variable Return On Income (BOPO) on Return On Equity (ROE) is 19.8\%, while the Equity (ROE). This means that the percentage of the influence of rest is influenced by other variables. 
Table 9. Coefficient of Determination with Dependent Variables Earning Per Share (EPS)

\begin{tabular}{lrrrr}
\hline \multicolumn{4}{c}{ Model Summary } \\
\hline Model & R & R Square & Adjusted R Square & Std. Error of the Estimate \\
\hline 1 & $.448^{\mathrm{a}}$ & .201 & .165 & 373.98793 \\
\hline a. Predictors: (Constant), NPL, BOPO & & & \\
b. Dependent Variable: EPS & & &
\end{tabular}

\author{
Source: Primary data processed, 2020
}

In Table 9, the determinant coefficient R2 is 0.201 for the dependent variable Earning Per Share (EPS). This means that the percentage of the effect of Non-Performing Loans (NPL) and Operating Costs Operating Income (BOPO) on Earning Per Share (EPS) is $20.1 \%$, the rest is influenced by other variables.

\section{Discussion}

1. Effect of Non-Performance Loans (NPL) and Operating Costs Operating Income (BOPO) on Return On Equity (ROE) at PT Bank Sahabat Sampoerna.

Non-Performance Loans (NPL) or non-performing loans are one of the key indicators for assessing the performance of bank functions. One of the functions of a bank is as an intermediary institution or a liaison between parties who have excess funds and those who need funds. Non-Performing Loan (NPL) is the rate of return on credit given by depositors to banks, in other words, NPL is the level of credit at the bank. The amount of NPL allowed by Bank Indonesia is currently a maximum of $5 \%$. NPL (Non-Performing Loan) is a ratio that shows the ability of bank management to manage non-performing loans provided by the bank.

According to Dendawijaya (2005), the ratio of operational costs is used to measure the level of efficiency and the ability of a bank to carry out its operations. Meanwhile, according to (Almilia and Herdiningtyas, 2005), the ratio of Operating Costs to Operating Income (BOPO) is often called the efficiency ratio, which is used to measure the ability of the bank management to control operating costs against operating income. The smaller the ratio, the more efficient the operational costs incurred by the bank concerned. Operating expenses are calculated based on the sum of total interest expense and total other operating expenses, and operating income is the sum of total interest income and total other operating income.

Return On Equity according to Sartono (2010: 124), which measures the company's ability to obtain available profits for the company's shareholders. Return On Equity according to Kasmir (2013: 204) is to measure net profit after tax with its capital. This Return On Equity ratio shows the efficient use of its capital. The higher the ratio, the better. This means that the company's position will be stronger, and vice versa.

Based on the results of descriptive statistics, it shows that the average NPL is more dominant than the standard deviation value. This shows that the data variation is very small because the standard deviation value is smaller than the mean. The BOPO average value is greater and the standard deviation value. It means that the standard deviation value is smaller than the mean, so the BOPO data has not much variation. The average ROE value which is the mediating variable in this study is greater than the standard deviation. This means that the ROE data is very high because the standard deviation value is smaller than the mean.
Based on the results of the path analysis, it shows that the value of Non-Performance Loans (NPL) gives an increase in Return On Equity (ROE). Likewise, Operating Costs Operational Income (BOPO) has an impact on Return On Equity (ROE). The results of this study are in line with research conducted by Monica (2019), John (2018), Saragih (2018), Muhamad (2015), Jihan Aprilia \& Siti Ragil Handayani (2018), Wismaryanto (2013).

2. The Influence of Non-Performance Loans (NPL) and Operating Costs Operating Income (BOPO) on Earning Per Share (EPS) at PT Bank Sahabat Sampoerna.

Shares can be defined as securities as evidence of participation or ownership of individuals or institutions in a company so that EPS can be inferred the value that makes investors spend their funds for investment to gain profit.

Earning Per Share (EPS) according to Husnan and Pudjiastuti (2004: 151) is the present value (Present Value) of income that will be received by investors and received by investors in the future. Meanwhile, according to Jogiyanto (2008: 143) Earning Per Share (EPS) is the price that occurs on the stock market at a certain time and the Earning Per Share (EPS) is determined by market players. The level of Earning Per Share (EPS) is determined by the demand and supply of these shares in the capital market.

Investors have various objectives in investing in the capital market, one of which is to gain profits on their share investment in the form of an increase in Earning Per Share (EPS) or dividends. Following the basic objective of a company, namely maximizing profits, every policy related to maximizing Earning Per Share (EPS) is always closely related to the company's ability to increase prosperity both to increase company value and to maximize the prosperity of its shareholders. According to Gitosudarmo and Basri (2002: 7) maximizing shareholder wealth can be measured from earnings per share (EPS) so that in this case EPS will affect investor confidence in the company.

Based on the results of descriptive statistics, it shows that the average NPL is more dominant than the standard deviation value. This shows that the data variation is very small because the standard deviation value is smaller than the mean. The BOPO average value is greater and the standard deviation value. It means that the standard deviation value is smaller than the mean, so the BOPO data has not much variation. The average ROE value which is the mediating variable in this study is greater than the standard deviation. This means that the ROE data is very high 


\section{Vol: 1, Issue: 2}

October $/ 2020$

https://ijbssrnet.com/index.php/ijbssr

DOI: 10.47742/ijbssr.v1n2p2

because the standard deviation value is smaller than the mean. Earning Per Share (EPS) which is the dependent variable in this study has a mean less than the standard deviation value. Because the standard deviation value has a value greater than the mean value, the data variation is large.

Based on the results of the path analysis, it shows that the value of Non-Performance Loans (NPL) does not increase Earning Per Share (EPS). However, Operating Costs Operating Income (BOPO) has an impact on Earning Per Share (EPS). The results of this study reject the research conducted by Monica (2019), John (2018), Saragih (2018), Muhamad (2015), Jihan Aprilia \& Siti Ragil Handayani (2018), Wismaryanto (2013).

\section{Effect of Return On Equity (ROE) on Earning Per Share} (EPS) at PT Bank Sahabat Sampoerna.

The average ROE value which is the mediating variable in this study is greater than the standard deviation. This means that the ROE data is very high because the standard deviation value is smaller than the mean. Earnings Per Share (EPS) which is the dependent variable in this study has a mean less than the standard deviation value. Because the standard deviation value has a value greater than the mean value, the data variation is large. Based on the results of path analysis, it shows that the value of Return On Equity (ROE) does not increase Earning Per Share (EPS).

The results of this study reject the research conducted by Wismaryanto (2013), Monica (2019), John (2018), Saragih (2018), Muhamad (2015), Jihan Aprilia \& Siti Ragil Handayani (2018), Wismaryanto (2013).

4. Effect of Non-Performance Loans (NPL) on Earning Per Share (EPS) through Return On Equity (ROE) at PT Bank Sahabat Sampoerna.

Based on the results of descriptive statistics, it shows that the average NPL is more dominant than the standard deviation value. This shows that the data variation is very small because the standard deviation value is smaller than the mean.

The average ROE value which is the mediating variable in this study is greater than the standard deviation. This means that the ROE data is very high because the standard deviation value is smaller than the mean. Earning Per Share (EPS) which is the dependent variable in this study has a mean less than the standard deviation value. Because the standard deviation value has a value greater than the mean value, the data variation is large. Based on the results of path analysis, it shows that the value of Return On Equity (ROE) has no impact on Earning Per Share (EPS). The results of this study are in line with research conducted by Sukarno (2006), and Hantono (2017). This research is not in line with Titiek Rachmawati \& Dwijono Kristijanto (2009).

\section{The Effect of Operating Costs Operating Income (BOPO) on Earning Per Share (EPS) through Return On Equity (ROE) at PT Bank Sahabat Sampoerna.}

Based on the results of descriptive statistics, the average BOPO value is greater and the standard deviation value. It means that the standard deviation value is smaller than the mean, so the BOPO data has not much variation.

The average ROE value which is the mediating variable in this study is greater than the standard deviation. This means that the
ROE data is very high because the standard deviation value is smaller than the mean. Earning Per Share (EPS) which is the dependent variable in this study has a mean less than the standard deviation value. Because the standard deviation value has a value greater than the mean value, the data variation is large. Based on the results of path analysis, it shows that the value of Return On Equity (ROE) does not increase Earning Per Share (EPS). The results of this study are in line with research conducted by Sukarno (2006), Jihan Aprilia \& Siti Ragil Handayani (2018). This research is not in line with Titiek Rachmawati \& Dwijono Kristijanto (2009).

\section{Conclusions and Recommendations} Conclusion

Based on the results of the research analysis and discussion, it can be concluded as follows:

1. The t-count value of the Non-Performance Loan (NPL) variable is 3.337 , while the t-table value is 1.687 . T-count> t-table (3.337> 1.687), thus $\mathrm{H} 0$ is rejected and $\mathrm{H} 1$ is accepted at the real level. This concludes that NonPerformance Loans (NPL) affect Return on Equity (ROE).

2. The t-count value of the Operational Cost of Operating Income (BOPO) is 2.184, while the t-table is $1.687 . \mathrm{T}$ count> t-table (2.184> 1.687), thus $\mathrm{H} 0$ is rejected and $\mathrm{H} 1$ is accepted at the real level. This concludes that the Operational Cost of Operating Income (BOPO) affects Return On Equity (ROE).

3. The t-count value of the Non-Performance Loan (NPL) variable is 1.380 , while the t-table value is 1.687 . T-count> t-table $(1.380<1.687)$, thus $\mathrm{H} 0$ is accepted and $\mathrm{H} 1$ is rejected at that real level. This concludes that the NonPerformance Loan (NPL) does not affect Earning Per Share (EPS).

4. The t-count value of the Operational Cost of Operating Income (BOPO) variable is 3.324 while the t-table is 1.687 . T-count $>$ t-table (3.324> 1.687), thus $\mathrm{H} 0$ is rejected and $\mathrm{H} 1$ is accepted at that real level. This concludes that the Operating Costs Operational Income (BOPO) affects Earning Per Share (EPS).

5. The results of the t-test for the variable Return On Equity (ROE) obtained the value of $t$ count $=1.434$, and the $t$-table of 1.687. This means that $t$-count $>$ t-table $(1.434<1.687)$, which means that $\mathrm{H} 0$ is accepted and $\mathrm{H} 1$ is rejected. This concludes that the Return On Equity (ROE) does not affect Earning Per Share (EPS).

6. The value of the indirect effect of 0.072 is obtained from the path coefficient value $\rho \times 3 \times 1$ multiplied by the path coefficient value $\rho y x 3$. The value of the direct effect of NonPerformance Loans (NPL) on Earning Per Share (EPS) is 0.145 . The multiplication result shows that the value of the indirect effect coefficient is smaller than the value of the direct effect coefficient. This shows that Return On Equity (ROE) cannot mediate, namely Non-Performance Loans (NPL) to Earning Per Share (EPS).

7. The value of the indirect effect of 0.047 is obtained from the path coefficient value $\rho \times 3 \times 1$ multiplied by the path 
coefficient value $\rho y x 3$. The value of the direct effect of NonPerforming Loans (NPL) on Earning Per Share (EPS) is 0.387. The multiplication result shows that the value of the indirect effect coefficient is smaller than the value of the direct effect coefficient. This shows that Return On Equity (ROE) cannot mediate, namely the Operational Cost of Operating Income (BOPO) to Earning Per Share (EPS).

\section{Recommendations}

The research results are expected to be useful both theoretically and practically, namely:

1. Developing theories related to Non-Performing Loans, Operating Costs Operating Income, Earning Per Share (EPS) and Return On Equity and enriching knowledge in general and the field of financial management in particular. In terms of investing in banks, it is better to choose a healthy bank by observing the high NPL will reduce the capital in the bank, because the income is used to cover the high NPL so that it will be followed by a decrease in funds distributed in the next period. This condition will hamper bank activities and will also reduce bank income so that high NPLs will result in low profitability.

2. For further researchers, it is suggested to be able to develop research by identifying other variables that can affect the Earning Per Share (EPS) of banks such as LDR, ROA, CAR and others and it is recommended to also look for a more accurate amount of data with a longer period.

3. The results of this study are expected to be able to provide information to investors in particular, because based on the results of this study, NPL or non-performing loans arising from bad credit from customers have a significant effect on Earning Per Share (EPS), as well as BOPO and ROE which are interrelated with Earning. Per Share (EPS) of the company. Therefore, to increase Earning Per Share (EPS), PT Bank Sahabat Sampoerna should pay attention to:

a. NPL (Non-Performance Loan) http://iarpnet.org/

Credit risk can also occur due to the failure or inability of the customer to repay the loan amount received from the bank and the interest according to a predetermined or scheduled period, thus the more non-performing loans the bank will have less opportunity to get a profit, resulting in a high NPL. Investors in banking will not be interested in buying stocks because the profits will be small.

b. BOPO, Operating Expenses on Operating Income (BOPO).

The BOPO ratio is also called the efficiency ratio. This ratio is used to measure the ability of bank management to control operating costs against operating income. The OEOI ratio is a comparison between operating costs and operating income. The smaller this ratio means the more efficient the operational costs incurred by the bank concerned so that the possibility of a bank being in a problematic condition will be smaller (Mahardian, 2008). Bank Indonesia determines the best figure for the BOPO ratio is below $90 \%$ because if the BOPO ratio exceeds $90 \%$ to close to $100 \%$, the bank can be categorized as inefficient in carrying out its operations.

c. Return On Equity (ROE)

ROE is a very important indicator for investors to determine the benefits obtained from investments invested in banking stocks. The higher the ROE, the more efficient the use of their capital is carried out by the management of the banking company to generate profits for shareholders. The increase in ROE indicates an increase in management's performance in managing existing sources of funds to generate profits and the value of ROE will increase so that investors are interested in buying these shares so that the company's Earning Per Share (EPS) will increase.

\section{References}

Agus Indriyo, Gitusudarmo dan Basri. (2002). Manajemen Keuangan. Yogyakarta: BPFE.

Agus Sartono. (2010). Manajemen Keuangan Teori dan Aplikasi. Edisi 4. Yogjakarta: BPFE.

Algifari, (1997), Analisis Statistik Untuk Bisnis; Dengan Regresi, Korelasi Dan Nonparametrik, Yogyakarta; BPFE.

Almilia \& Herdiningtyas, (2005), “ Analisis Rasio CAMEL terhadap Prediksi Kondisi Bermasalah Pada Lembaga Perbankan Periode 2000-2002", Jurnal Akuntansi dan Keuangan, Vol.7, No.2, November.

Aviliani, Hermanto, Maulana dan Hasanah, (2015). The Impact Of Macro Economic Condition On The Bank Is Performance In Indonesia. Buletin Ekonomi Dan Moneter Dan Perbankan, Vol 17. Nomor 4, April 2015.

Bank of Indonesia. (2014). Statistik Ekonomi Indonesia. Bank Indonesia, Jakarta.

Brigham, Eugene dan Joel F Houston, (2010). Manajemen Keuangan II. Jakarta:Salemba Empat.

Christiano, Mario; Parengkuan Tommy; Ivonne Saerang. (2014). Analisis terhadap Rasio-Rasio Keuangan untuk Mengukur Profitabilitas pada Bank-Bank Swasta yang Go Public di Bursa Efek Indonesia. ISSN 2303-1174. Jurnal EMBA. Volume 2. Nomor 4.

Damodaran, Aswath. (2002). Investment Valuation Toll and Technique for Determining The Value of Any Assets, university edition. John Willey and Sons, inc. Newyork.

Danang, Sunyoto. (2013). Metodologi Penelitian Akuntansi. Bandung: PT Refika Aditama Anggota Ikapi.

Daniarto Raharjo, Dul Muid. (2013). Analisis Pengaruh Faktor-Faktor Fundamental Rasio Keuangan Terhadap Perubahan Harga Saham. Volume 2, Nomor 2, Tahun 2013, Halaman 1-11. 


\section{Vol: 1, Issue: 2}

October/2020

https://ijbssrnet.com/index.php/ijbssr

DOI: 10.47742/ijbssr.v1n2p2

Dendawijaya, Lukman, (2005). Manajemen Perbankan, Edisi Kedua, Cetakan Kedua, Ghalia Indonesia, Bogor Jakarta.

Eng, Tan Sau. (2013). Pengaruh NIM, BOPO, LDR, NPL, dan CAR Terhadap ROA Bank Intrnasional dan Bank Nasional Go Public Periode 2007- 2011. Jurnal Dinamika Manajemen. Volume 1, No. 3. Halaman 153- 167.

Fahmi, Irham. (2012). “Analisis Kinerja Keuangan", Bandung: Alfabeta.

Ghozali, Imam. 2011. “Aplikasi Analisis Multivariate Dengan Program SPSS”. Semarang: Badan Penerbit Universitas Diponegoro. Hantono (2017), Effect Of Capital Adequacy Ratio (CAR), Loan To Deposit Ratio (LDR), and Non-Performing Loan (NPL) To Return On Assets (ROA) Listed In Banking In Indonesia Stock Exchange. International Journal of Education and Research. Vol.5. No. 1. January.

Husnan, Suad., Enny Pudjiastuti, (2004). Dasar-Dasar Manajemen Keuangan. Edisi Keempat, Yogyakarta, UPP AMP YKPN.

Jihan Aprilia \& Siti Ragil Handayani, (2018). Pengaruh Capital Adequancy Ratio, Biaya Operasional Per Pendapatan Operasional, Non Performing loan Dan Loan To Deposit Ratio Terhadap Return On Asets Dan Return On Equity (Studi pada Bank Umum Swasta Nasional Devisa Tahun 2012-2016). Jurnal Administrasi Bisnis (JAB). Vol. 61. No. 3. Agustus.

Jogiyanto. (2008). Teori Portofolio dan Analisis Investasi. Edisi Kelima, BPFE. Yogyakarta.

John, Timothy Amos, (2018), Effect of Non-Performing Loans on Bank Performance of Some Selected Commercial Bank in the Nigerian Banking Sector. International Journal of New Technology and Research. (IJNPR). Vol. 04/4/April. pp. 11-17.

Kartika Wahyu Sukarno, (2006), Analisis Faktor-Faktor Yang Mempengaruhi Kinerja Bank Umum Di Indonesia. Jurnal Studi Manajemen dan Organisasi. Vol. 3 No.2, Juli.

Kasmir. (2013). “Analisis Laporan Keuangan”. Edisi 1. Cetakan ke-6. Jakarta: Rajawali Pers.

Kuncoro dan Suhardjono, (2002), Manajemen Perbankan (Teori dan Aplikasi), Edisi Pertama, Penerbit BPFE, Yogyakarta Kuncoro, Mudrajad. (2002). Metode Riset untuk Bisnis \& Ekonomi. Jakarta: Erlangga.

Lestari, Maharani Ika dan Toto Sugiharto. (2007). Kinerja Bank Devisa Dan Bank Non Devisa Dan Faktor-Faktor Yang Mempengaruhinya. Proceeding PESAT (Psikologi, Ekonomi, Sastra, Arsitek \& Sipil). 21-22 Agustus, Vol.2. Fakultas Ekonomi, Universitas Gunadarma.

Mohd. Heikal, Muammar Khaddafi, Ainatul Ummah, (2014). Influence Analysis of Return On Assets (ROA), Return On Equity (ROE), Net Profit Margin (NPM), Debt To Equity Ratio (DER), and current ratio (CR), Against Corporate Profit Growth In Automotive In Indonesia Stock Exchange. International Journal of Academic Research in Business and Social Science. Dec 2014. Vol.4. No. 12

Monica, (2019), Analisis Pengaruh CAR, NPL, NIM, BOPO Dan LDR Terhaadap ROE Pada Bank Umum Swasta Nasional Devisa Di Indonesia. Jurnal Manajemen Bisnis dan Kewirausahaan. Vol.3/3, Mei 2019.pp 08-17.

Nahdia Kinanti Muhamad, (2015), Pengaruh CAR, NPL, DAN BOPO Terhadap Profitabilitas Dan Return Saham Pada Bank-Bank Yang Terdaftar Di BEI Tahun 2009-2013. Jurnal EMBA. Vol. 3 No.2. Juni.

Nyarko, (2018), Effects of Non-Performing Loans on the Profitability of Commercial Banks - A Study of Some Selected Banks on the Ghana Stock Exchange. Global Journal of Management and Business Research: Finance. Vol. 18. Issue 2.

Sugiyono, (2016), Metode Penelitian Kuantitatif, Kualitatif dan R\&D. Bandung: PT Alfabet.

Swastha, Basu dan Irawan. (2011), Manajemen Pemasaran Modern . Yogyakarta : Liberty.

Syamsuddin, Lukman. (2009). Manajemen Keuangan Perusahaan: Konsep Aplikasi dalam: Perencanaan, Pengawasan, dan Pengambilan Keputusan. Jakarta: Rajawali Pers.

Tandelilin, Eduardus. (2010). Teori Portofolio dan Investasi. Yogyakarta: Kanisius.

Titiek Rachmawati \& Dwijono Kristijanto. (2009), Pengaruh Return On Assets (ROA), Return On Equity (ROE), Net Interest Margin (NIM) Dan Rasio Biaya Operasional Pendapatan Operasional (BOPO), Terhadap Harga Saham Bank Di Bursa Efek Indonesia. Jurnal Ilmu Ekonomi dan Manajemen. Vol. 6, No.1.

Wiguna, Robin dan Anastasia Sri Mendari.2008: 10. Pengaruh Earning Per Share Dan Tingkat Bunga SBI Terhadap Harga Saham Pada Perusahaan Yang Terdaftar Di LQ 45 BEI. Jurnal Keuangan dan BisnisVol 6, No.2 : 130-142

Wismaryanto, Sigit Dwi (2013), Pengaruh NPL, LDR, ROA, ROE, NIM, BOPO, Dan CAR Terhadap Harga Saham Pada Sub Sektor Perbankan Yang Terdaftar Di Bursa Efek Indonesia Tahun 2008 - 2012. Jurnal Manajemen. Vol.3 No.1. Juni. 